\title{
Differences In The Effectiveness Of Massage Tuina And Grant Aromatherapy Oil Lemongrass (Cymbopogonnardus) In Overcoming Difficulties Eating In Children In The Work Area Health Balowerti Kediri City
}

\author{
Halimatus Sa'idah*,Rahma Kusuma Dewi \\ Faculty of Health Sciences, Kadiri University, Indonesia \\ *halimatus.saidah@unik-kediri.ac.id
}

\begin{abstract}
Nutritional intake is an important aspect in growth and development of toddlers. Optimal nutritional intake will support optimal growth and development in future life. To meet these nutritional needs, there are many obstacles, especially regarding the eating behavior of toddlers. In Indonesia in 2012 there were around 53\% of children under the age of 5 suffering from malnutrition due to a lack of food to meet their daily nutritional needs (Ministry of Health, 2012) having difficulty eating which is caused by several factors, if not carried out properly, the problem of eating in the long term will cause a disturbance in nutritional status. Giving Lemongrass Oil Aromatherapy (Cymbogon Nardus) and Tuina Massage can be used as alternative treatments to overcome feeding difficulties in toddlers. The purpose of this study was to determine the difference in the effectiveness of Citronella Aromatherapy (Cymbogon Nardus) and Tuina Massage in overcoming feeding difficulties in toddlers. The research design was Two Group Pre Test Post Test Design with a population of children under five (12-59 months) who had difficulty eating totaling 32 respondents, 16 respondents were treated with citronella oil aromatherapy intervention and 16 respondents were given the intervention of massage with natural data using Wilcoxon and different tests using Man. Whitney. The results showed that there is a difference between giving lemongrass oil aromatherapy with tuina massage in overcoming feeding difficulties in toddlers $\left(\mathrm{P}_{-}\right.$Value $\left.=0,000\right)$.
\end{abstract}

Keywords: Lemongrass Aromatherapy (Cymbofogon Nardus), Tuina Massage, Feeding Difficulties, Toddlers 


\section{STRADA Jurnal Ilmiah Kesehatan}

DOI: $10.30994 /$ sjik.v9i2.467

ISSN: 2252-3847 (print); 2614-350X (online)

Vol.9 No.2 November 2020 Page.1309-1322

\section{BACKGROUND}

Children under five have their own characteristics in various areas of growth and development.growth and Biologicaldevelopment (Astuti and Ayuningtyas 2018), toddler age is a golden period in growth and development and is a critical period for determining physical and mental development in future life (Munjidah 2018). A balanced and nutritious diet is essential during this period.

In this period, they are passive consumers, meaning that children receive food from what their mother provides (Astuti and Ayuningtyas 2018). Parents play an important role in fulfilling these nutrients so that nutritional problems and developmental disorders in toddlers can be reduced, most parent-child interactions occur during feeding, feeding infants and toddlers is considered a natural process, however, 50-60\% of parents report that their child has problems eating (Sjarif et al. 2014). Feeding difficulties that occur in toddlers can cause decreased immune system, sleep disturbances, balance and coordination disorders, children become aggressive, impulsive and stunted. (Munjidah 2018)

The problem of stunting in toddlers is still a national problem and is included in the four national health program. In the 2015-2019 health development, stunting (short children under five) with a target of reducing the incidence of stunting to $28 \%$ (Djauhari 2017). In $201722.2 \%$ or around 150.8 million children under five in the world were stunted. According to WHO data, Indonesia is one of the third countries with the highest prevalence in Southeast Asia. The average prevalence of stunting under five in Indonesia in 2005-2017 is 36.4\%. Based on Nutritional Status Monitoring (PSG) data for the last three years, the incidence of stunting has the highest prevalence compared to other nutritional problems such as malnutrition, wasting, and obesity (Ministry of Health of the Republic of Indonesia 2018), Stunting in children under five is caused by lack of food intake and recurring diseases especially infectious diseases that can increase metabolic needs and reduce children's appetite. (LPPM STIKes Hang Tuah Pekanbaru 2015)

Symptoms of difficulty eating in children are $25 \%$, this number will increase by around $40-70 \%$ of under-five. Difficulty eating is often experienced by children, especially the age range of 1-3 years which is called the age of jag food, where children only eat food they like or even have difficulty eating (Soedibyo and Mulyani 2016). Difficulty eating is the child's inability to consume the amount of food he needs, the prevalence of eating difficulty behavior quite high. Research in Singapore shows the proportion of difficulty eating the highest at the age of 3-5 years is 29.9 (Khaq, Yuniastuti, and Rahayu 2018). The prevalence of eating difficulties in children in Taiwan aged 3-5 years is 72\% (Abell 2006) Meanwhile, the proportion of eating difficulties in Indonesia it is $60.3 \%$ higher at the age of under five, the behavior of food voters occurs when children reach the age of 2 to 3 years. (Di, Xii, and Play 2020)

Research on preschool children aged 4-6 years in Jakarta found a prevalence of eating difficulties of $33.6 \%, 44.5 \%$ of whom suffer from mild to moderate malnutrition, and $79 \%$ have lasted more than three months . (Soedibyo and Mulyani 2016)

Feeding difficulties can be refusal behavior (neophobia), limited variety of food types, completely rejecting foods that you don't like, and only wanting to eat foods you like (Di, Xii, and Play 2020)

In general The causes of difficulty eating in toddlers are divided into 3 factors, including prolonged loss of appetite in toddlers, disorders of the digestive tract and disruption of the eating process or oral motor disorders. (Astuti and Ayuningtyas 2018)

These eating problems will have a negative impact on children's health, such as growth problems, risk of infection and even death,in addition, eating problems have the 


\section{STRADA Jurnal Ilmiah Kesehatan}

DOI: $10.30994 /$ sjik.v9i2.467

ISSN: 2252-3847 (print); 2614-350X (online)

Vol.9 No.2 November 2020 Page.1309-1322

potential to cause cognitive impairment. and behavior, as well as the risk of anxiety disorders and eating disorders (eating disorders) in children, adolescents, and young adults (Sjarif et al. 2014)

Behavior difficulty eating makes it difficult for children to accept food, children become fussy when given inappropriate food so that children do not enjoy the food served. This also affects the number of food variations received so that it requires special food serving techniques that need to be done so that children easily accept food (Mascola et al., 2010). Limited food variations will affect the intake of protein, energy, meat and vegetables (van der Horst et al., 2016). Research conducted Galloway, et al., (2008) stated that children with eating difficulties experience lower fat intake when compared to children who do not have difficulty eating. (Purnamasari and Adriani 2020) .

Management of eating difficulties is generally done by giving multivitamins to children regardless of the cause of the eating problems. This will have a negative impact if given for a long time. (Ningsih, Kuntari, and Dermawan 2011)

Efforts to overcome eating difficulties can be done by pharmacological and nonpharmacological methods. Efforts with pharmacology include giving milltivitamins and micronutrients other. Meanwhile, non-pharmacology includes herbal drinks, massage, acupressure and acupuncture. Recently, it has been developed from baby massage techniques, namelymassage, which is a massage Tui $\mathrm{Na}$ technique to overcome feeding difficulties in toddlers by improving blood circulation to the spleen and digestion, through modification of acupuncture without needles (MJ 2018).

Research conducted by Happy Marthalena at the Baawang Community Health Center in Palangkaraya in 2019 on 15 babies showed that there was a significant effect of tuina massage on increasing feeding difficulties for toddlers before and after massage, where 15 respondents $(100 \%)$ had difficulty in their toddlers' appetite before the massage was carried out. eat. After a massage that was not difficult to eat, there were 13 respondents (86.7\%) and 2 respondents $(13.3 \%)$ who still had difficulty eating (Simanungkalit 2020)

Apart from using the tuina massage there was also Aromatherapy. Based on several studies, plant sources used for aromatherapy as an appetite enhancer are; Lemongrass leaves (Soedarsono 2009)

The content in citronella essential oil is citronellal (35.9\%), citronellal $(5.2 \%)$, geraniol $(20.9 \%)$, geranial $(1.5 \%)$, citronyl acetate ( $2.9 \%)$, geranil acetate $(4.0 \%)$, germacrene $b(6.8 \%)$, and $\alpha$-kardinol $(8.0 \%)$. Lemongrass herbs contain saponins, flavonoids, polyphenols, methyl heptanone, terpenes, and terpenes alcohol. Lemongrass oil is generally used as a mosquito repellent, but nowadays lemongrass oil can also be used as a medicinal ingredient, for example: it can stretch stiff muscles, and as an appetite enhancer. (Ariyani, Setiawan, and Soetaredjo 2008)

Lemongrass oil aromatherapy Fragrant psychologically and physically through the activation of the limbic system gives a signal that the smell will be delivered toarea olfactory the lateral in the cerebral cortex and then delivered to the limbic system. Through the hypothalamus, this signal will be processed and delivered to the amygdala and produce emotions for the smell that has been inhaled, besides that when the stimulation is delivered to the autonomic central nervous system in the spinal cord, it will activate the inhibitory effect of the sympathetic system and strengthen the parasympathetic system (Guyton, 2006). Part of the aromatherapy that is applied will be inhaled, the volatile molecules of the oil are carried by air currents to the "roof" of the nose in manacilia -cilia the softarise from thecells receptor. When the molecules attach to the 


\section{STRADA Jurnal Ilmiah Kesehatan}

DOI: $10.30994 /$ sjik.v9i2.467

ISSN: 2252-3847 (print); 2614-350X (online)

Vol.9 No.2 November 2020 Page.1309-1322

hairs, an electro-chemical message is transmitted through theducts olfactory into the limbic system. This will stimulate memory and emotional response. The hypothalamus acts as a relay and regulator, giving rise to messages that must be conveyed to other parts of the brain as well as to other parts of the body. The message received is then converted into an action in the form of the release of neurochemical compounds such as serotonin and enkephalin which cause euphoria, relaxation and sedatives. (Koensoemardyah 2009)

Use of Lemongrass Aromatherapy to Increase Appetite on the skin of the palms, feet and chest when toddlers sleep for 1 week successively. (Fatmawati, As, and Toddlers 2014)

\section{METHODS}

This study is a pre-experimental study with the Two Group Pre Test and Post Test Design approach to determine the difference between Giving Lemongrass Oil Aromatherapy (Cymbofogon Nardus) and Tuina Massage in overcoming feeding difficulties in toddlers. The population in this study were toddlers (1-59 months) who had difficulty eating, a sample of 32 respondents, 16 respondents were given lemongrass oil intervention (Cymbofogon Nardus) and 16 respondents were given tuina massage intervention. The sampling technique used wastechnique. purposive sampling The research instrument used a questionnaire. and SOP on the use of Citronella Aromatherapy and Tuina Massage. Aromatherapy Lemongrass oil is given for 1 week given $3 \mathrm{X} 1$ days before eating while tuina massage is given by means of $1 \mathrm{x}$ therapy protocol per day, for 6 consecutive days. The research was conducted in Semampir Village, the Working Area of the Balowerti Health Center in July-August 2020. The variables in this study consisted of independent variables, namely the provision of tuina massage $\left(\mathrm{X}_{1}\right)$ and the provision of lemongrass oil / lemongras aromatherapy $\left(\mathrm{X}_{2}\right)$ and the dependent variable was the difficulty of eating under five. before and after being given tuina massage and aromatherapy. Data were analyzed using analyzed using Wilcoxon and Mann Whitney.

\section{RESEARCH RESULTS}

\section{General Data}

Table 1. Characteristics of Toddlers with Eating Difficulties in Kelurahan Semampir Work Area of Balowerti

\begin{tabular}{ccccccc}
\hline Category & $\begin{array}{c}\text { Aromatherapy Intervention } \\
\text { Lemongrass Oil }\end{array}$ & $\begin{array}{c}\text { Massage Tuina } \\
\text { Intervention }\end{array}$ & Total \\
\hline Sex & $\mathbf{f}$ & $\mathbf{\%}$ & $\mathbf{f}$ & $\mathbf{\%}$ & $\mathbf{F}$ & $\mathbf{\%}$ \\
\hline Male & 8 & 50 & 4 & 25 & 12 & 37.5 \\
\hline Female & 8 & 50 & 13 & 81.25 & 20 & 62.5 \\
\hline Total & 16 & 100 & 16 & 100 & 32 & 100 \\
\hline Gender & & $\mathbf{f} \%$ & & $\mathbf{f} \%$ & $\mathbf{F} \%$ \\
\hline $\begin{array}{c}12 \text { months } 24 \\
\text { months }\end{array}$ & 12 & 75 & 8 & 50 & 20 & 62.5 \\
\hline $\begin{array}{c}25 \text { months-36 } \\
\text { months }\end{array}$ & 4 & 25 & 8 & 50 & 12 & 37.5 \\
\hline Total & 16 & 100 & 16 & 100 & 32 & 100 \\
\hline Children & to-f & $\mathbf{\%}$ & $\mathbf{f}$ & $\mathbf{\%}$ & $\mathbf{F}$ & $\mathbf{\%}$ \\
\hline
\end{tabular}


STRADA Jurnal Ilmiah Kesehatan

DOI: $10.30994 /$ sjik.v9i2.467

ISSN: 2252-3847 (print); 2614-350X (online)

Vol.9 No.2 November 2020 Page.1309-1322

\begin{tabular}{|c|c|c|c|c|c|c|}
\hline 1 & 6 & 37.5 & 6 & 37.5 & 12 & 37.5 \\
\hline 2 to 4 & 5 & 31.25 & 9 & 56.25 & 14 & $\begin{array}{c}43.7 \\
5\end{array}$ \\
\hline$>4$ & 5 & 31.25 & 1 & 6.25 & 6 & $\begin{array}{c}18.7 \\
5\end{array}$ \\
\hline Total & 16 & 100 & 16 & 100 & 32 & 100 \\
\hline Parents Education & f & $\%$ & f & $\%$ & $\mathbf{F}$ & $\%$ \\
\hline Basic & 4 & 25 & 2 & 12.5 & 6 & $\begin{array}{c}18.7 \\
5\end{array}$ \\
\hline Medium & 6 & 37.5 & 10 & 62.5 & 16 & 50 \\
\hline High & 6 & 37.5 & 4 & 25 & 10 & $\begin{array}{c}31.2 \\
5\end{array}$ \\
\hline Total & 16 & 100 & 16 & 100 & 32 & 100 \\
\hline $\begin{array}{c}\text { Parents' } \\
\text { occupation }\end{array}$ & f & $\%$ & f & $\%$ & $\mathbf{F}$ & $\%$ \\
\hline IRT & 4 & 25 & 4 & 25 & 8 & 25 \\
\hline Self-employed & 3 & 18.75 & 5 & 31.25 & 8 & 25 \\
\hline PNS & 2 & 12.5 & 2 & 12.5 & 4 & 12.5 \\
\hline Private Employees & 7 & 43.75 & 3 & 18.75 & 10 & $\begin{array}{c}31.2 \\
5\end{array}$ \\
\hline Others & 0 & 0 & 2 & 12.5 & 2 & 6.25 \\
\hline Total & 16 & 100 & 16 & 100 & 32 & 100 \\
\hline $\begin{array}{c}\text { Basic Feeding } \\
\text { Rules }\end{array}$ & f & $\%$ & f & $\%$ & $\mathbf{F}$ & $\%$ \\
\hline Yes & 5 & 31.25 & 4 & 25 & 9 & 28.1 \\
\hline No & 11 & 68.75 & 12 & 75 & 23 & 71.9 \\
\hline Total & 16 & 100 & 16 & 100 & 32 & 100 \\
\hline Nutritional status & f & $\%$ & f & $\%$ & $\mathbf{F}$ & $\%$ \\
\hline Less & 6 & 37.5 & 8 & 50 & 14 & $\begin{array}{c}43.7 \\
5\end{array}$ \\
\hline Good & 10 & 62.5 & 8 & 50 & 18 & $\begin{array}{c}56.2 \\
5\end{array}$ \\
\hline More & 0 & 0 & 0 & 0 & 0 & 0 \\
\hline Total & 16 & 100 & 16 & 100 & 32 & 100 \\
\hline
\end{tabular}

Table 1 on the characteristics of toddlers who have difficulty eating in Semampir Village, Balowerti Work Area based on gender in the intervention group giving lemongrass oil (Cymbofogon Nardus) half (50\%) were male and female with 8 respondents each. In the tuina massage intervention group, it can be seen that almost all of them $(81.25 \%)$ are female, amounting to 13 respondents.

Characteristics of children under five who have difficulty eating in the Semampir Village, Balowerti Working Area based on age in the intervention group of giving lemongrass oil (Cymbofogon Nardus), most of them (75\%) were 12-24 months, amounting to 12 respondents while in the intervention group half tuina massage (50\%) 12-24 months old and 25 months to 36 months, respectively amounting to 8 respondents.

Characteristics of toddlers who have difficulty eating in Semampir Village Balowerti Work Area based on Children To what extent in the family in the intervention group of 


\section{STRADA Jurnal Ilmiah Kesehatan}

DOI: $10.30994 /$ sjik.v9i2.467

ISSN: 2252-3847 (print); 2614-350X (online)

Vol.9 No.2 November 2020 Page.1309-1322

giving lemongrass oil (Cymbofogon Nardus) almost half (37.5\%) was the 1st child, amounting to 6 respondents while in the intervention group tuina massage most $(56.25 \%)$ were the 2 nd to 4 th children, amounting to 9 respondents.

The characteristics of toddlers who have difficulty eating in the Semampir Village, Balowerti Work Area based on the education of parents in the intervention group giving lemongrass oil (Cymbofogon Nardus) almost half (37.5\%), namely middle and high education, amounting to 6 respondents each, while in the group Most of the tuina massage intervention $(62.5 \%)$ had secondary education, namely 16 respondents.

The characteristics of toddlers who have difficulty eating in the Semampir Village, Balowerti Work Area based on the work of parents in the intervention group giving lemongrass oil (Cymbofogon Nardus) almost half $(43.75 \%)$ as private employees, amounting to 7 respondents, while in the intervention group tuina massage almost half $(31.25 \%)$ as entrepreneurs, amounting to 5 respondents.

The characteristics of toddlers who have difficulty eating in Semampir Village, Balowerti Work Area are based on the basic feeding rule behavior applied by parents in the intervention group giving lemongrass oil (Cymbofogon Nardus) most (68.75\%) did not apply the basic feeding rule behavior, namely 11 respondents, Meanwhile, in the tuina massage intervention group, the majority (75\%) did not apply the basic feeding rule, namely 23 respondents.

Characteristics of toddlers who have difficulty eating in Semampir Village, Balowerti Work Area based on nutritional status (BW / U) in the intervention group giving lemongrass oil (Cymbofogon Nardus) most (62.5\%) have good nutritional status, amounting to 10 respondents while the massage intervention tuina half $(50 \%)$ had good and poor nutritional status, namely 8 respondents respectively.

\section{Custom Data}

a. Difficulties Eating Behavior In Toddlers Before awarded Aromatherapy Citronella Oil (Cymbofogon nardus) in the Village Puskesmas Balowerti Semampir of Kediri

Table 2. Difficulty Eating Behavior In Toddlers in Semampir Village Puskesmas Balowerti of Kediri

\section{No Category Difficulty Eating $\quad$ F $\quad$ Pesentase (\% )}

\begin{tabular}{lccc}
\hline 1 & Low & 6 & 37.5 \\
\hline 2 & Moderate & 6 & 37.5 \\
\hline 3 & High & 4 & 25 \\
\hline & Total & 16 & 100 \\
\hline
\end{tabular}

Based on table 2 about the behavior of eating difficulties in children under five in Semampir Village, the working area of Balowerti Health Center, Kediri City, before being givenintervention (citronella aromatherapyCymbofogon Nardus) almost half (37.5\%) having difficulty eating low and moderate, amounting to 6 respondents respectively. 


\section{STRADA Jurnal Ilmiah Kesehatan}

DOI: $10.30994 /$ sjik.v9i2.467

ISSN: 2252-3847 (print); 2614-350X (online)

Vol.9 No.2 November 2020 Page.1309-1322

b. Feeding Difficulty Behavior of Toddlers After being given Lemongrass Oil Aromatherapy (Cymbofogon Nardus) in Semampir Village, the Working Area of Puskesmas Balowerti, Kediri City.

Table 3. The behavior ofdifficulty eating after being given toddlers withlemongrass oil aromatherapy (Cymbofogon Nardus) in Semampir Village, the working area of Puskesmas Balowerti, Kediri.

\begin{tabular}{cccc}
\hline No & Category Difficulty Eating After & F & $\begin{array}{c}\text { Percentage } \\
(\mathbf{\%})\end{array}$ \\
\hline 1 & Low & 11 & 68.8 \\
\hline 2 & Medium & 5 & 31.3 \\
\hline 3 & High & 0 & 0 \\
\hline & Total & $\mathbf{1 6}$ & $\mathbf{1 0 0}$ \\
\hline
\end{tabular}

Based on table 3 about the behavior of eating difficulties in children under five in Semampir Village, the working area of Balowerti Health Center, Kediri City after being given citronella Aromatherapy intervention (Cymbofogon Nardus) mostly (68.8\%) had difficulty eating low, as many as 11 respondents.

c. Eating Difficulty Behavior in Toddlers Before being given Tuina Massage in Semampir Village, the Working Area of the Balowerti Health Center, Kediri.

Table 4. Eating Difficulty Behavior of Toddlers Before being given Tuina Massage in Semampir Village Work Area of the Balowerti Health Center Kediri City

\begin{tabular}{cccc} 
No & Eating Difficulty Category Before & F & $\begin{array}{c}\text { Percentage } \\
(\mathbf{\%})\end{array}$ \\
\hline 1 & Low & 3 & 18.8 \\
\hline 2 & Medium & 5 & 31.3 \\
\hline 3 & High & 8 & 50 \\
\hline & Total & 16 & 100 \\
\hline
\end{tabular}

Based on table 4 regarding Behavior of eating difficulties in children under five in Semampir Village, the working area of Puskesmas Balowerti, Kediri, before being given the tuina massage intervention, almost half (31.3\%) experienced moderate eating difficulties, amounting to 5 respondents. 


\section{STRADA Jurnal Ilmiah Kesehatan}

DOI: $10.30994 /$ sjik.v9i2.467

ISSN: 2252-3847 (print); 2614-350X (online)

Vol.9 No.2 November 2020 Page.1309-1322

d. Eating Difficulty Behavior in Toddlers Before being given Tuina Massage in Semampir Village, the Working Area of the Balowerti Health Center, Kediri.

Table 5. Eating Difficulty Behavior in Toddlers After being given Tuina Massage in

Semampir Village, Kediri City Balowerti Health Center Work Area

No Eating Difficulty Category After $\quad$ F $\quad \begin{gathered}\text { Percentage } \\ (\%)\end{gathered}$

\begin{tabular}{cccc}
\hline 1 & Low & 9 & 56.3 \\
\hline 2 & Medium & 7 & 43.8 \\
\hline 3 & High & 0 & 0 \\
\hline & Total & 16 & 100
\end{tabular}

Based on table 5 about the behavior of eating difficulties in children under five in Semampir Village, the Working Area of the Balowerti Health Center, Kediri City, after being given tuina massage intervention, almost half (43.8\%) experienced moderate eating difficulties, namely 7 respondents.

e. The Effect of Lemongrass Oil (Cymbofogon NardusAroamotherapy)in Overcoming Feeding Difficulties in Toddlers in Kelurahan Semampir, the working area of Puskesmas Balowerti, Kediri City.

Table 6. Effect of Lemongrass Oil (Cymbofogon NardusAroamtherapy) in Overcoming Feeding Difficulties in Toddlers in Semampir Village, the Area Working of Puskesmas Balowerti, Kediri City.

\begin{tabular}{|c|c|c|c|c|c|c|}
\hline \multirow{3}{*}{$\begin{array}{l}\text { Category of } \\
\text { Difficulty in } \\
\text { Eating Before } \\
\text { Intervention of } \\
\text { Aromatherapy } \\
\text { Lemongrass Oil }\end{array}$} & \multicolumn{4}{|c|}{$\begin{array}{c}\text { Category of Difficulty in Eating After } \\
\text { Aromatherapy Intervention of } \\
\text { Lemongrass Oil }\end{array}$} & \multirow{2}{*}{\multicolumn{2}{|c|}{ Total }} \\
\hline & \multicolumn{2}{|c|}{ Low } & \multicolumn{2}{|c|}{ Moderate } & & \\
\hline & $\mathrm{F}$ & $\%$ & $\mathrm{f}$ & $\%$ & $\mathrm{~F}$ & $\%$ \\
\hline Low & 6 & 100.0 & 0 & 0.0 & 6 & 100.0 \\
\hline Moderate & 4 & 66.7 & 2 & 33.3 & 6 & 100.0 \\
\hline High & 1 & 25.0 & 3 & 75.0 & 4 & 100.0 \\
\hline Total & 11 & 68.8 & 5 & 31.3 & 16 & 100.0 \\
\hline \multicolumn{7}{|c|}{ P_Value: $0.007 \alpha: 0.005$} \\
\hline Negative Rar & & Positive & s 0 & Ties $8^{c}$ & & \\
\hline
\end{tabular}

Based on table 6 it can be seen that of the 6 respondents who had moderate eating difficulties before being given the intervention giving lemongrass aromatherapy (Cymbofogon Nardus) after being given intervention most of them (66.7\%) have low eating difficulties as many as 4 respondents.

Based on statistical tests using the Wilcoxon test with a significance level $(\alpha: 0.05)$, it was obtained $\mathrm{P}_{-}$value $0.007\left(\mathrm{P}_{-}\right.$value $<\alpha$ : 0.05$)$ so that it was concluded that there was an effect between giving lemongrass oil aromatherapy (Cymbofogon Nardus) on feeding 


\section{STRADA Jurnal Ilmiah Kesehatan}

DOI: $10.30994 /$ sjik.v9i2.467

ISSN: 2252-3847 (print); 2614-350X (online)

Vol.9 No.2 November 2020 Page.1309-1322

difficulties in toddlers. With a Negative Rank of $8^{\mathrm{a}}$, which means there are 8 respondents who experienced a decrease in symptoms of difficulty eating, Positive Ranks $0^{\mathrm{b}}$ which means that no one has an increase in symptoms of difficulty eating, and ties Ties $8 \mathrm{c}$ is obtained which means there are still 8 respondents who do not experience changes in difficulty eating after being given citronella oil aromatherapy intervention (Cymbofogon Nardus)

f. The Effect of Tuina Massage Aromatherapy in overcoming Feeding Difficulties in Toddlers in Semampir Village, the Working Area of Puskesmas Balowerti, Kediri City.

Table 7. The Effect of Lemongrass Oil (Cymbofogon NardusAroamotherapy)in theArea

Overcoming Feeding Difficulties in Toddlers in Semampir Village,

Workingof Puskesmas Balowerti, Kediri City.

\begin{tabular}{|c|c|c|c|c|c|c|c|}
\hline \multirow{3}{*}{$\begin{array}{c}\text { Feeding } \\
\text { Difficulty } \\
\text { Category Before } \\
\text { Tuina Massage } \\
\text { Intervention } \\
\end{array}$} & \multicolumn{4}{|c|}{$\begin{array}{l}\text { Category Eating Difficulty After } \\
\text { Intervention Tuina Massage }\end{array}$} & \multirow{2}{*}{\multicolumn{3}{|c|}{ Total }} \\
\hline & \multicolumn{2}{|c|}{ Low } & \multicolumn{2}{|c|}{ Moderate } & & & \\
\hline & $\mathrm{F}$ & $\%$ & $\mathrm{f}$ & $\%$ & $\mathrm{~F}$ & & $\%$ \\
\hline Low & 3 & 100.0 & 0 & 0.0 & & 3 & 100.0 \\
\hline Moderate & 3 & 60.0 & 2 & 40.0 & & 5 & 100.0 \\
\hline High & 3 & 37.5 & 5 & 62.5 & & 8 & 100.0 \\
\hline Total & 9 & 56.3 & 7 & 43.8 & & 16 & 100.0 \\
\hline \multicolumn{8}{|c|}{ P_Value: $0.002 \alpha: 0.002$} \\
\hline
\end{tabular}

Based on table 7 it can be seen that of the 8 respondents who had severe eating difficulties before being given the intervention to give tuina massage after being given the intervention, most $(62, \% \%)$ had moderate eating difficulties, namely 9 totaled 5 respondents and almost half $(37.5 \%)$ had difficulties. eat low, namely 3 respondents.

Based on statistical tests using the Wilcoxon test with a significance level $(\alpha: 0.05)$, it was obtained $\mathrm{P}_{\text {_value }} 0.002(\mathrm{P}$ _value $<\alpha: 0.05)$ so that it was concluded that there was an effect between giving lemongrass oil aromatherapy (Cymbofogon Nardus) on feeding difficulties in toddlers. With Negative Ranks $11^{\mathrm{a}}$, which means there are 11 respondents who experience a decrease in symptoms of difficulty eating, Positive Ranks $0^{\mathrm{b}}$ which means no one has experienced an increase in symptoms of difficulty eating, and ties Ties $5 \mathrm{c}$ is obtained, which means there are still 5 respondents who do not experience changes in difficulty eating after being given tuina massage intervention. 


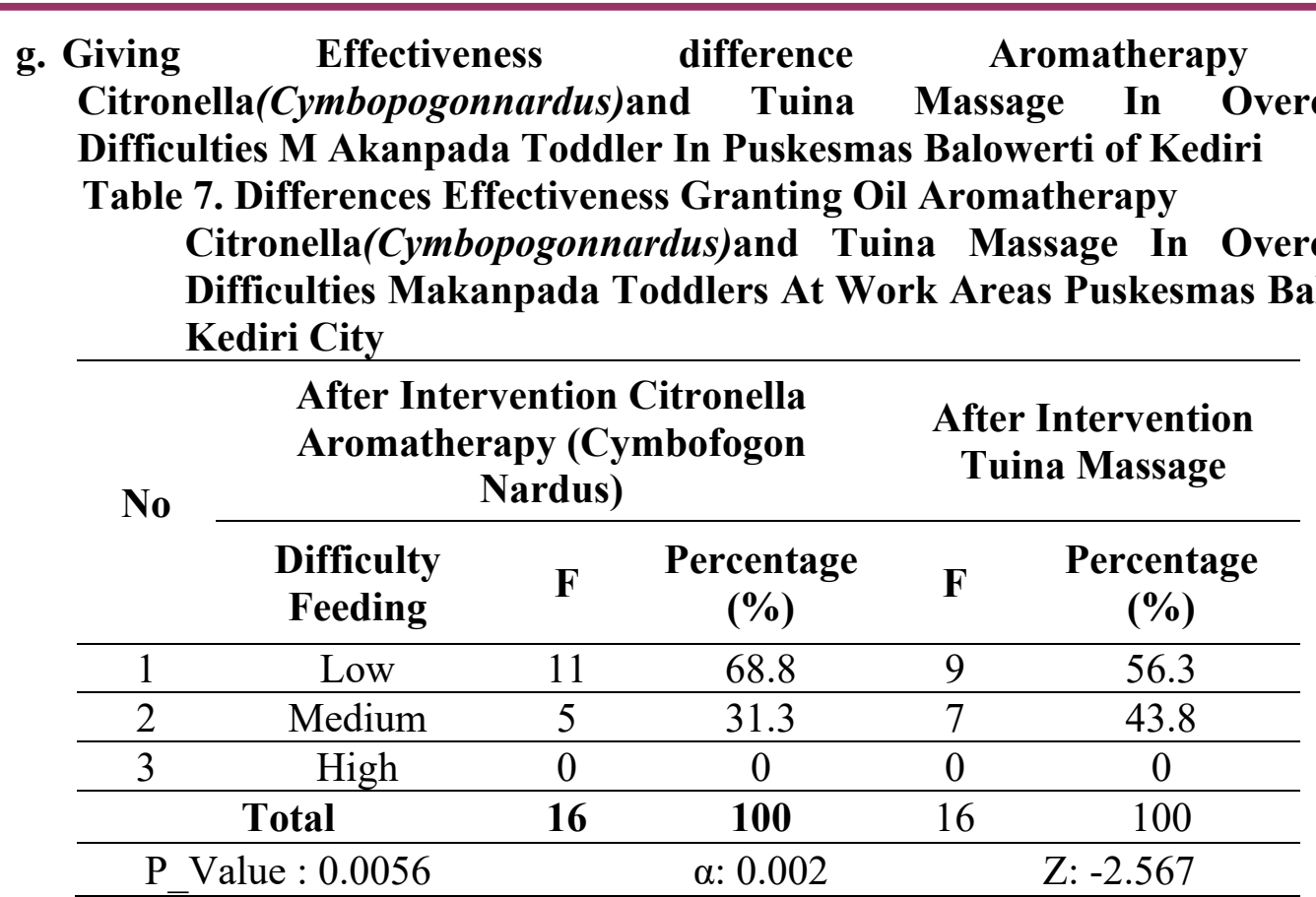

Based on statistical tests using the Wilcoxon test, the values of $Z$ :obtained 2.567 and Asymp were. Sig. (2-tailed) 0.0056 so that $\left(\mathrm{P}_{-}\right.$value $<\alpha$ : 0.05 ) aka $\mathrm{H}_{0}$ is rejected and $\mathrm{H}_{1}$ is accepted, it can be concluded that there is a difference in the effectiveness of tuina massage and the provision of lemongrass oil aromatherapy (Cymbopogon Nardus) in overcoming feeding difficulties in toddlers in the Work Area Puskesmas Balowerti Kediri City.

So, the Tuina Massage Intervention is more effective in overcoming feeding difficulties in toddlers. This can be seen based on the value of the Negative Rank and $\rho_{-}$ value of each intervention. Intervention massage Tuina obtained Negative Ranks $11^{\mathrm{a}}$ and P_VALUE 0002 while intervention Aromatherapy Oil Citronella Negative Ranks $8^{\mathrm{a}}$ and P_VALUE 0,007

\section{DISCUSSION}

Based on the results ditabel 6 can be seen that out of 6 respondents Representatives have difficulty eating were before given intervention Award aromatherapy citronella oil (Cymbofogon nardus ) after being given the intervention, most (66.7\%) had low eating difficulties, namely 4 respondents.

Based on statistical tests using the Wilcoxon test with a significance level ( $\alpha: 0.05)$, it was obtained $\mathrm{P}_{-}$value 0.007 ( $\mathrm{P}_{-}$value $<\alpha: 0.05$ ) so that it was concluded that there was an effect between giving lemongrass oil aromatherapy (Cymbofogon Nardus) on feeding difficulties in toddlers. With a Negative Rank of $8^{\mathrm{a}}$, which means there are 8 respondents who experienced a decrease in symptoms of difficulty eating, Positive Ranks $0^{\mathrm{b}}$ which means that no one has an increase in symptoms of difficulty eating, and ties Ties $8 \mathrm{c}$ is obtained which means there are still 8 respondents who do not experience changes in difficulty eating After being given lemongrass oil aromatherapy intervention (Cymbofogon Nardus).

From the results of this study, it can be seen that there is a change in the behavior of eating difficulties, the origin of which is that the difficulty eating behavior is having difficulty eating in the low category. 


\section{STRADA Jurnal Ilmiah Kesehatan}

DOI: $10.30994 /$ sjik.v9i2.467

ISSN: 2252-3847 (print); 2614-350X (online)

Vol.9 No.2 November 2020 Page.1309-1322

Difficulty eating in children is one that parents often complain about when they go to a polyclinic or a practice place, and one of the developmental disorders that can occur in healthy babies or children. About $25 \%$ of children with normal development and $80 \%$ of children with developmental disabilities report eating problems. (Gurnida nd)

Feeding difficulties in children is a problem that is very often faced by parents, doctors and other health workers. The complaints that often arise are that children don't want to eat, refuse to eat, the process of eating takes too long, they only want to drink, if they are fed they vomit, complain of stomach pain, and some are told to eat angry and even angry. Complaints that often appear in toddlers show signs of difficulty eating disorders. (Fatmawati, As, and Toddler 2014).

The results of research on the effectiveness of lemongrass oil have been conducted by Ery Fatmawati regarding the use of aromatherapy as a stimulation to increase food intake in toddlers, indicating that the use of citronella oil aromatherapy has no significant difference $(\mathrm{P}>0.05)$ in the intake of staple foods, vegetables, while there are differences that significant in the intake of animal side dishes.

Aromatherapy of fragrant lemongrass oil psychologically and physically through the activation of the

limbic system gives a signal that the smell will be delivered to the lateral olfactory area in the cervical cortex and then delivered to the limbic system. Through the hypothalamus, this signal will be processed and delivered to the amygdala and produce emotions for the smell that has been inhaled, besides that when the stimulation is delivered to the autonomic central nervous system in the spinal cord, it will activate the inhibitory effect of the sympathetic system and strengthen the parasympathetic system (Guyton, 2006). Part of the aromatherapy that is applied will be inhaled, the volatile molecules of the oil are carried by the air currents to the "roof" of the nose where the soft cilia arise from the receptor cells. When the molecules attach to the hairs, an electro-chemical message is transmitted through the olfactory ducts into the limbic system.

This will stimulate memory and emotional response. The hypothalamus acts as a relay and regulator, giving rise to messages that must be conveyed to other parts of the brain as well as to other parts of the body. The message received was then converted into an action in the form of the release of neurochemical compounds such as serotonin and enkephalin which caused euphoria, relaxation, and sedatives. (Sari and Widyaningrum 2018)

Based on table 7 it can be seen that of the 8 respondents who had difficulty eating heavy before being given massage interventions After being given the intervention, most of them $(62, \% \%)$ had moderate eating difficulties, namely 9 totaled 5 respondents and almost half $(37.5 \%)$ had low eating difficulties, namely 3 respondents.

Based on statistical tests using the Wilcoxon test with a significance level $(\alpha: 0.05)$, it was obtained $\mathrm{P}_{\text {_value }} 0.002\left(\mathrm{P}_{-}\right.$value $<\alpha$ : 0.05$)$ so that it was concluded that there was an effect between giving lemongrass oil aromatherapy (Cymbofogon Nardus) on feeding difficulties in toddlers. With Negative Ranks $11^{\mathrm{a}}$, which means there are 11 respondents who experience a decrease in symptoms of difficulty eating, Positive Ranks $0^{\mathrm{b}}$ which means no one has experienced an increase in symptoms of difficulty eating, and ties Ties $5 \mathrm{c}$ is obtained which means there are still 5 respondents who do not experience changes in difficulty eating after being given tuina massage intervention.

The results showed that the respondents who had Tuina Massage tended to have an increased appetite. So that it provides information that the Tuina Massage performed on toddlers can have an effect, namely increasing appetite. The results of this study were 


\section{STRADA Jurnal Ilmiah Kesehatan}

DOI: $10.30994 /$ sjik.v9i2.467

ISSN: 2252-3847 (print); 2614-350X (online)

Vol.9 No.2 November 2020 Page.1309-1322

strengthened by the research of Lourence 2007 where the results showed that there was an effect of Tuina Massage on toddlers with an increase in appetite (Munjidah 2018).

The results of this study are in line with the theory which states that stimulation of Tuina Massage is to provide massage to the nerve endings found on the surface of the skin. (Massage will result in the permeability of the cell membrane thinning so that it will facilitate the exchange of sodium $(\mathrm{Na})$ and potassium $(\mathrm{Ka})$ ions which will stimulate the potential for muscles and nerves. Action potential that occurs on the sympathetic and sympathetic nerves will affect the work of the organs, among others: stimulation The Vagus Nerve will affect the Gastrointestinal system, namely increased peristalsis so that gastric emptying increases due to rapid hunger (appetite will increase) and eating becomes ravenous. In addition there will also be an increase in the production of digestive enzymes which will help the absorption of nutrients. the absorbed will enter the blood circulation which also increases due to stimulation from the sympathetic nerves. (Indrayani 2015)

After the Tui $\mathrm{Na}$ massage there are still 5 respondents who do not experience changes in appetite, maybe there are other factors that cause children to experience difficulty eating. The causes of eating problems vary widely, giving rise to various classifications of eating problems with their respective advantages. Based on the Diagnosis of State and Mental Disorders-IV (DSM-IV), eating problems are classified into three groups, namely feeding disorder of infancy or early childhood, pika, and rumination. Bonin divides eating problems based on three causes, namely structural abnormalities, abnormalities neurodevelopmental, and eating behavior problems.Chatoor classified eating difficulties into six groups and emphasized more on eating behavior problems, while Kerzner divided eating problems into four large groups, namely limited appetite, highly selective intake, colic, and fear of feeding.(Sjarif et al. 2014)

Based on statistical tests using the Wilcoxon test, $\mathrm{Z}$ values were obtained: 2.567 and Asymp. Sig. (2-tailed) 0.0056 so that ( $\mathrm{P}_{-}$value $<\alpha$ : 0.05 ) aka $\mathrm{H}_{0}$ is rejected and $\mathrm{H}_{1}$ is accepted, it can be concluded that there is a difference in the effectiveness of tuina massage and the provision of lemongrass oil aromatherapy (Cymbopogon Nardus) in overcoming feeding difficulties in toddlers in the Work Area Puskesmas Balowerti Kediri City.

From the results of this study, it can be seen that there are differences in effectiveness there are differences in the effectiveness of tuina massage and lemongrass oil aromatherapy (Cymbopogon Nardus) in overcoming feeding difficulties in toddlers in the Public Health Balowerti Work Area, Kediri City, and Tuina Massage has higher effectiveness than the use of Aromatherapy Oil. lemongrass.

The increase in appetite for toddlers with tuina massage intervention was caused by the Tuina massage. This is because giving Tuina Massage helps improve blood circulation and can maximize organ function, one of the organs that can be maximized is the digestive organ. Where with massage the intestinal motility will increase and will improve the absorption of nutrients by the body and increase appetite while in aromatherapy lemongrass oil is caused because the smell of lemongrass oil is inhaled and increases brain parasympathetic to increase appetite in toddlers. Although both have influence, there are differences in effectiveness and many factors cause it.

Research on the effectiveness of using lemongrass to increase appetite is rarely done, litter usually has benefits for mosquito repellents, antiseptics, beauty products, massage oils and stress relief. (Suwarmi, A, Ariani Hesti W 2010) 


\section{STRADA Jurnal Ilmiah Kesehatan}

DOI: $10.30994 /$ siik.v9i2.467

ISSN: 2252-3847 (print); 2614-350X (online)

Vol.9 No.2 November 2020 Page.1309-1322

Mean while, for the effectiveness of tuina massage in increasing appetite, there have been many research studies which state that tuina massage has an effect on increasing appetite.

As in the research conducted by Asniar in Bombana Regency, before the Tuina Massage treatment, the average appetite level of toddlers was $44.87 \%$, while the average appetite level of toddlers after Tuina Massage was $66.66 \%$ with a significant value smaller than $0,05(0.000<0.05)$. (Naningsi and Malahayati 2019)

Tuina massage can increase growth, increase endurance, build bonds of affection for parents and children, reduce stress and irritability, improve muscle tone, accelerate the development of the brain and nervous system. Massage can only be done once a day for 6 consecutive days. In general, 1 massage series above is enough to do, if you feel the need to add a new massage, you should give a break of 1-2 days before doing a new massage series. (Da Silva, Lorenzi-Filho, and Lage 2007)

\section{CONCLUSION}

There is a difference in effectiveness between tuina massage and lemongrass oil aromatherapy (Cymbofogon Nardus), and tuina massage has a higher effectiveness than lemongrass aroamotherapy intervention (Cymbofogon Nardus). Suggestions for further research are that before giving intervention it is necessary to look at the causes of eating difficulties first so that treatment will be more effective.

\section{REFERENCES}

Abell, Sue. 2006. 'Picky Eater'. Clinical Pediatrics 45 (4): 385-86.

Ariyani, Fransiska, Laurentia Eka Setiawan, and Felicia Edi Soetaredjo. 2008. 'Extraction

Of Essential Oil From Sereh Plants Using Methanol, Acetone, And n-Hexane Solvent'. Widya Teknik.

Astuti, Endah Puji, and Ika Fitria Ayuningtyas. 2018. 'Picky Eater Behavior and Nutritional Status in Toddlers'. Midwifery Journal: UM Midwifery Journal. Mataram 3 (1): 81.

Di, Tahun, RW Xii, and Playgroup. 2020. 'Picky Eater Behavior Description And Background Factors In Children 2-4 AGE'. 5: 39-48.

Djauhari, Thontowi. 2017. 'Nutrition And 1000 HPK'. Saintika Medika.

Fatmawati, Ery, Use of Aromatherapy as, and Food Intake for Toddlers. 2014. 'Ery Fatmawati', .

Gurnida, Dida A. 'Management of Feeding Difficulties in Children'. : 1-10.

Indriyani, Irma. 2015. 'The Influence of Baby Massage, Faculty of Health Sciences UMP, 2016'. 3 (2010): 2010-13.

Ministry of Health RI. 2018. 'Pusdatin: Stunting Bulletin'. Indonesian Ministry of Health 1: 2.

Khaq, Arrina Ell, Ari Yuniastuti, and Sri Ratna Rahayu. 2018. 'An Analysis of Picky Eater Towards Growth and Motor Development at Kebasen District Health Center'. An Analysis of Picky Eater Towards Growth and Motor Development at Kebasen District Health Center 3 (3): 224-30.

Koensoemardyah. 2009. AZ Aromatherapy For Health, Fitness And Beauty. Yogyakarta: Lily Publisher.

LPPM STIKes Hang Tuah Pekanbaru. 2015. 'Stunting Problems and Interventions to Prevent Stunting (A Literature Review) Stunting Problems and Interventions to 


\section{STRADA Jurnal Ilmiah Kesehatan}

DOI: $10.30994 /$ sjik.v9i2.467

ISSN: 2252-3847 (print); 2614-350X (online)

Vol.9 No.2 November 2020 Page.1309-1322

Prevent Stunting (A Literature Review)'. Journal of Community Health 2 (6): 254-61. http://ejournal.htp.ac.id/stikes/pdf.php?id=JRL0000099.

MJ, Afridawaty. 2018. 'How Women To Overcome Difficulty Of Eating Pre-School Children In The Village Of Penyengat Olak, Muaro Jambi District, 2015'. Batanghari University Scientific Journal, Jambi.

Munjidah, Annif. 2018. 'The Effectiveness Of Tui Na Massage In Overcoming Difficulties In Eating Children At Rw 02 Kelurahan Wonokromo Surabaya'. Journal of Health Sciences.

Naningsi, Hasmia, and Andi Malahayati. 2019. 'Public Health Mataoleo District Bombana Year 2019 Publication Text Of The Ministry Of Health Of The Republic Of Indonesia Department Of Midwifery D-IV Prodi'.

Ningsih, Ayu Widya, Titik Kuntari, and MTS Dermawan. 2011. 'Comparison of Increasing Mother's Knowledge About Baby Massage After Getting Counseling and VCD Screening in Widodomartani Village, Ngemplak, Sleman, Yogyakarta'. 3: 13-19.

Purnamasari, Aditia Rida, and Merryana Adriani. 2020. 'The Relationship between Picky Eater Behavior and Adequacy Levels of Protein and Fat in Preschool Children'. Media Gizi Indonesia 15 (1): 31-37.

Sari, Defie Septiana, and Nova Rahma Widyaningrum. 2018. 'The Effect of Aromatherapy of Lemongrass Oil (Cymbopogon Citratus) on the Prevention of Postpartum Blues in Primipara Women at Sukoharjo District Hospital'. Indonesian Journal On Medical Science.

Da Silva, Gerson D., Geraldo Lorenzi-Filho, and Lais V. Lage. 2007. 'Effects of Yoga and the Addition of Tui $\mathrm{Na}$ in Patients with Fibromyalgia'. Journal of Alternative and Complementary Medicine.

Simanungkalit, Happy Marthalena. 2020. 'The Effect of Massage on the Difficulty Level of Feeding in 1 Year Old Toddlers'. Information Media 15 (2): 96-100.

Sjarif, Damayanti Rusli et al. 2014. 'Recommendations by the Indonesian Pediatrician Association on the Diagnosis and Management Approach of Eating Problems in Toddlers in Indonesia'. http://spesialis1.ika.fk.unair.ac.id/wpcontent/uploads/2017/03/Rek.

Soedarsono. 2009. Medicinal Plants. Yogyakarta: Gadjah Mada University.

Soedibyo, Soepardi, and Raden Lia Mulyani. 2016. 'Feeding Difficulties in Patients: A Survey in the Pediatric Outpatient Unit'. Sari Pediatrics.

Suwarmi, A, Ariani Hesti W, Siti Munisih. 2010. 'The use of lemongrass oil into various products'. Indonesian Pharmaceutical Media 12: 69-73 